\title{
Dissemination of Information Communication Technologies: Mobile Government Practices in Developing States
}

\author{
Mustafa Bal'1, Cem Gonenc Biricik ${ }^{1}$ Arif Sari ${ }^{2}$ \\ ${ }^{1}$ Department of Management Information Systems, European University of Lefke, Lefke, Cyprus \\ ${ }^{2}$ Department of Management Information Systems, Girne American University, Kyrenia, Cyprus \\ Email: mustafabal93@hotmail.com,gonencbiricik@gmail.com, arifsari@gau.edu.tr
}

Received 11 February 2015; accepted 27 December 2015; published 30 December 2015

Copyright (C) 2015 by authors and Scientific Research Publishing Inc.

This work is licensed under the Creative Commons Attribution International License (CC BY).

http://creativecommons.org/licenses/by/4.0/

(c) (j) Open Access

\section{Abstract}

Information Communication Technologies (ICT) has offered m-government applications as an intermediate technology to provide effective and efficient government services to the public. Due to high rate of corruptions in developing states, government policies diversified governmental services from offline to virtualized perspective to expose accessibility, transparency, accountability and accessibility through mobile government. Deployment of such ICT tool also exposed a unique opportunity for the recovery of the public confidence against government which has damaged due to corruption activities in country. Virtualization of the government services became compulsory due to high rate of corruption that occurred in the economic context and it became a serious obstacle for economic development of developing states. The virtualized services aimed to harmonize governmental services into mobile platform in order to become more transparent to the public. This research paper comparatively investigates the mobile government services that are located in Malta and Singapore which are classified as developing countries. The criteria of the comparison have done based on demographic structure of the country, M-government policies and ICT infrastructure of the country. The findings of this study exposed the impact of e-government practices and differences between them in terms of applicability and provide a specific point of view for m-government adoption policy.

\section{Keywords}

M-Government, Developing States, Virtualization, ICT, Policy, Malta, Singapore 


\section{Introduction}

Nowadays, mobile government applications developed to provide service to citizens of developed and developing countries more efficiently, effectively and quickly. E-government applications of information and communication technologies in a guided way to mobilize the services offered to the citizens are the simplest definition of the mobile government. The spread usage of mobile services forced new transition of e-government services inevitably to mobility [1]-[4]. In today's world that globalizing, science and technology more accelerated day by day, ICT is now being leverage for other sectors ceased to be a branch of technology [3]-[5]. Basic ICT infrastructure of developing states countries such as Singapore and Malta are investigated to expose current state of mobile government in Malta, its effectiveness and efficiency, usage and assess the overall mobile government strategy. ICT is one of the indispensable elements of life in economic and social life. Variety of country uses ICT in the public sector more consistently, tended to structure offering cheap and accurate services where this structure is defined as e-government. Most important in the country's service sector is among the reasons for the importance of mobile research and development had given the state administration, the country's population density varies in importance given to the technology of the population and by the country of service. In this article, the mobile application of the two island nations government, unlike other countries, to draw attention to the importance it attaches to research and development has been requested. As little more than the population of the Maltese government had to the need for research and development of the Maltese island country wants to develop the smart vision and need for appropriate research and development of the later start of the state of the mobile government applications development within singapore government has taken care to provide more slowly by the Maltese government and development. Using technological possibilities of access to ICT and public services citizens in this way to get more efficient and higher quality services indicate a need beyond necessity. ICT are closer to the state government to ensure citizens facilitate knowledge management [6]-[8]. Today the development of smart phones is leaded the possibility of access to these services 24/7 through M-government concept. Through the streamlined infrastructure used by M-government structure, E-government services provide anytime access of citizens. In order to create specific attention and desire on m-government, mobile applications are crucially important. To expose a state of m-government applications and the interest-awareness of the citizens, fast, flexible and evolving mobile applications compatible with country's internet and mobile communication infrastructure is compulsory. The research also highlights the state of the m-government resources that these countries have and devoted to provide m-government services in country.

ICT is one of the indispensable elements of life in economic and social life. World using ICT in the public sector more consistent, tended to structure offering cheap and accurate service. This structure is defined as egovernment. Using technological possibilities of access to ICT and public services citizens in this way to get more efficient and higher quality services indicate a need beyond necessity. ICT are closer to the state government to ensure citizens facilitate knowledge management [8]-[10]. Today has led the development of smart phones and the people that develop quickly turned to the state and to turn to smartphone applications to access tivity in terms of sectors. M-government, e-government anytime access of citizens created using streamlined infrastructure has to be provided. To develop a state of m-government applications and the interest in it to the citizens to make continuous mobile application and the information is easy to develop applications, to be fast and flexible, evolving according to the country's internet and mobile communication infrastructure. The amount of the state of the resources they devote to providing the importance of m-government applications development.

\section{ICT in Developing States}

Information Communication Technologies (ICT), which combines computer and communication technologies, information constituting any kind of printed and written information that is accessible by others and visual tools [11]. The vital importance of ICT is to make people's life easier through technological innovations. ICT industry evolved variety of techniques in terms of closing the gap between developing countries and developed countries [12] [13]. ICT is used with the aims towards developing state of the social and economic objectives and can be used as the key to achieve of the state strategy goals. Developing states are able to implement ICT to the most of sectors such as governance, business and education. In order to achieve such goal, country communication infrastructure must be developed and ready to adopt ICT innovations which are quite difficult for developing regions in the world. 


\section{M-Government}

E-Government: Using the state's duty is to fulfill against citizens and services with citizens, state that the duties and responsibilities of the electronic communications and computing environments in a continuous and safe execution of the M state experienced in the real-life state for more efficient operation of e-government in terms of accessibility wireless internet infrastructure mobile applications are moving to laptops [14] [15]. The development of service models is shown on the Figure 1 below.

Mobile government is a state of providing all e-government services to public through mobile environment with the advantage of the mobile technology. The rapid changes in technological innovations and impact of the Internet forced e-government state to be changed and spread into mobile environment [17].

The successful adoption of the Mobile Government is possible through designing an M-government applications to have an easy access, functional and non-complex interface for the citizens. The digital government strategy is also defined by US and basic conceptual model is designed by considering different principles [17][19]. While designing of mobile government applications, it must be user-centered design and ubiquitous, efficient, transparent and innovative.

\subsection{M-Government in Developing States}

The spread of ICT all around the world lead many opportunities and practical solutions to improve the utilization of resources in developing states. As a result of technological innovations on public services and quality, the cost of services significantly decreased.

Governments have proposed e-government services in mobile platforms after exposing the demand of mobility and necessity of dissemination in e-services in countrywide. Applications derived from e-government in mobile platform have also been supporter for government services where an application illustrates the importance of ease of use and anytime access. Developing countries needs to mobile government. Governments enable country's citizens to engage with an increasingly mobile workforce to access high-quality mobile government services at anywhere, anytime and on any device [20]-[22]. Today, e-government services provide information related with technology, public safety, health, accommodation and emergency.

\subsection{M-Government Policies}

Government must be able to provide uninterrupted information services to public with quality and provide sustainable information participation of citizen's with engagement of mobile government applications. Mobile

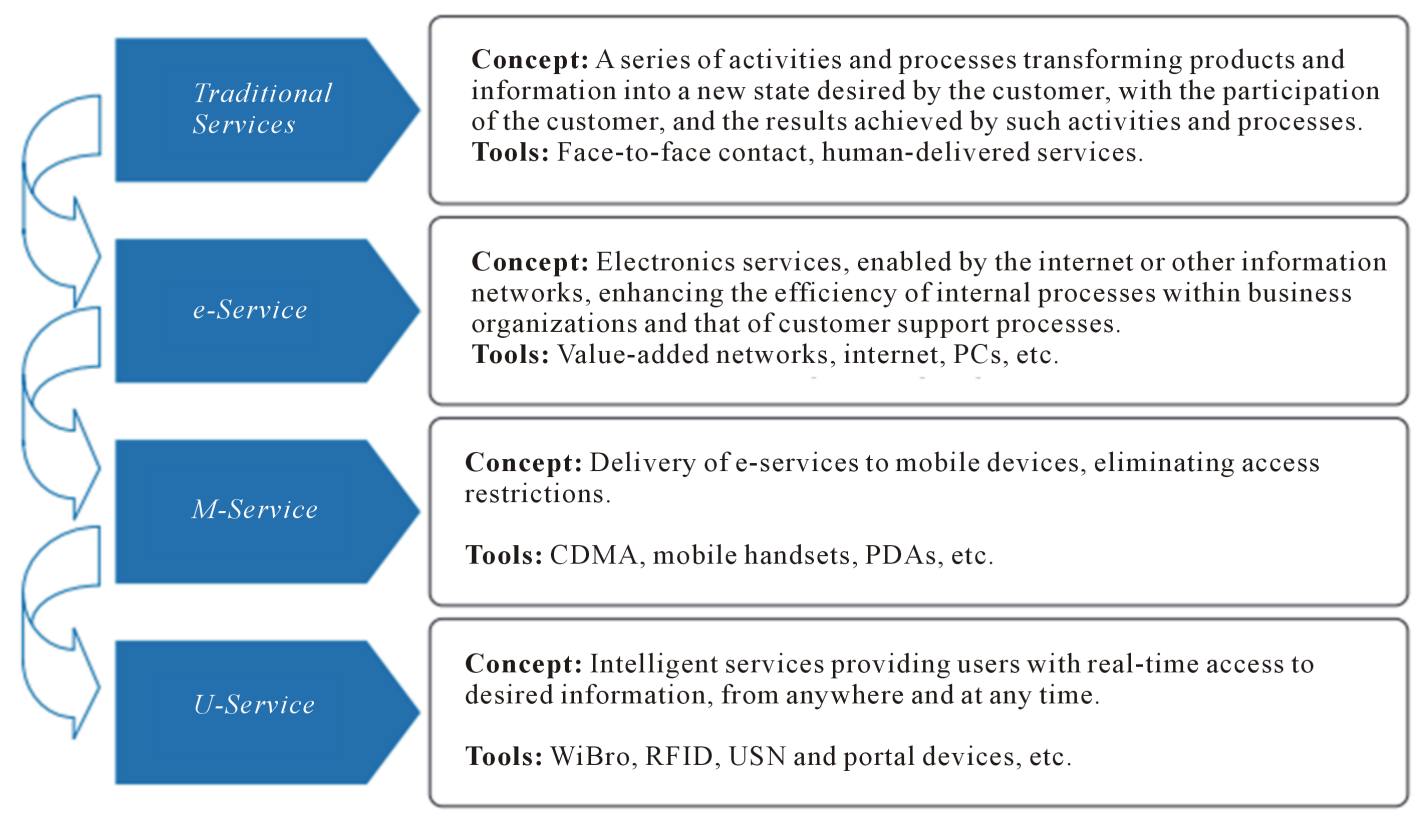

Figure 1. Development of service concepts [16]. 
devices allow users to conduct convenient operation and 24 hours effectively-sustainable information sharing through e-government applications. Today, citizen monitoring applications and services used by national government to facilitate the collection of statistics and operations of the state, public services and information about the public. Additionally, Mobile Applications used to track of citizens tax payments and legal transactions resulting in the reduction of transaction of paper [23].

\section{M-Government in Malta (Institutions, Development and Strategies)}

A Malta has started Mobile government applications and virtualization from 2002 to the applications they are developing, especially since citizen-centered paradigm and in line with the mission.

The small population of the Maltese government, Information and resources that it allocates the correct and effective use of informatics and communication technologies has led to rapid progress in Communication Technology [24]. Malta Ministry of Information Technologies in 2004 identified 13 strategic goals made and published. This strategy covers the current period as well as branding strategy Intelligent Island in 2008-2010 (The Smart Island strategy), as a result of Malta's strategy was done in previous years occurred.

Government and including the industrial action Informatics of the new generation in this package and Communication Technology infrastructure and development, intelligent workforce development, a better life using information and communications technologies for the quality, improve public services and to facilitate the management is of the e-commerce development objectives [24] [25]. In 2000, only 28\% of the Maltese Maltese citizens are using a telephone but in 2007 , this rate was $86.6 \%$ and in $2013,137.18 \%$ out on the general population of mobile subscriptions Figure 2. PCI in 2007 by the NSO and MIIT Malta are given statistics of the Internet and mobile use [14].

Figure 3 gives the statistics of mobile strategy of the Maltese government (Malta Ministry for Investment, Industry and Information Technology, 2008).

$\begin{array}{lll}\text { Percentage } & \text { Indicator } & \text { Source } \\ 86.6 \% & \text { Mobile subscriptions as a percentage of population } & \text { NSO, 2007 } \\ 70.3 \% & \text { Percentage of households with a PC } & \text { NSO/MIIIT, 2007 } \\ 45.9 \% & \text { Percentage of individuals (18+) using the computer frequency } & \text { NSO/MIIIT, 2007 } \\ 22 & \text { Internet subscriptions per 100 persons, not households } & \text { NSO, 2007 } \\ 63 \% & \text { Individuals with access to the Internet } & \text { NSO/MIIT, 2007 } \\ 80 \%(\text { of } 63 \%) & \text { Individuals with access to the Internet with a broadband connection } & \text { NSO/MIIIT, 2007 } \\ & & \end{array}$

Figure 2. PCI in 2007 by the NSO.

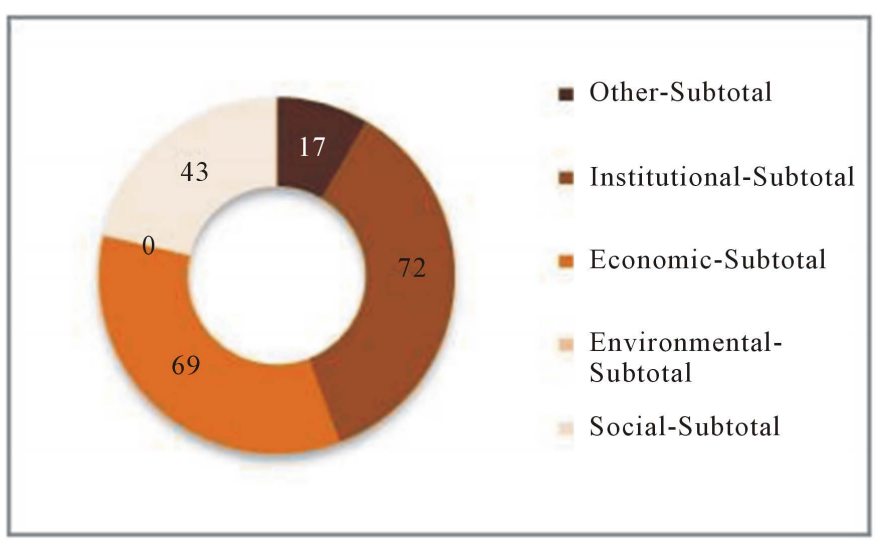

Figure 3. Number of MGOV strategies for SD (Sustainable Development) dimensions—-Malta. 
According to the statistics of the Maltese government enterprise (72) follow immediately after the economy is mainly a strategy (69) and social development (43) seems to give importance [24]-[27].

Figure 3 shows the strategy of Malta's individual mobile state sustainable development goals. In turn, the development in the Maltese national Information and Communication Technology: corporate through corporate development, services and applications, Innovation Systems and Infrastructure sizes, social development and innovation system, Figure 4. The Figure 5 is an illustration of the tabulated data [28].

Support received from external sources of Malta, the advantage of the small population, it is seen that the source of accurate time and because the site in place using importance is given to the ICT infrastructure and mobile state of development of the state policy today an important place in the mobile state of Malta.

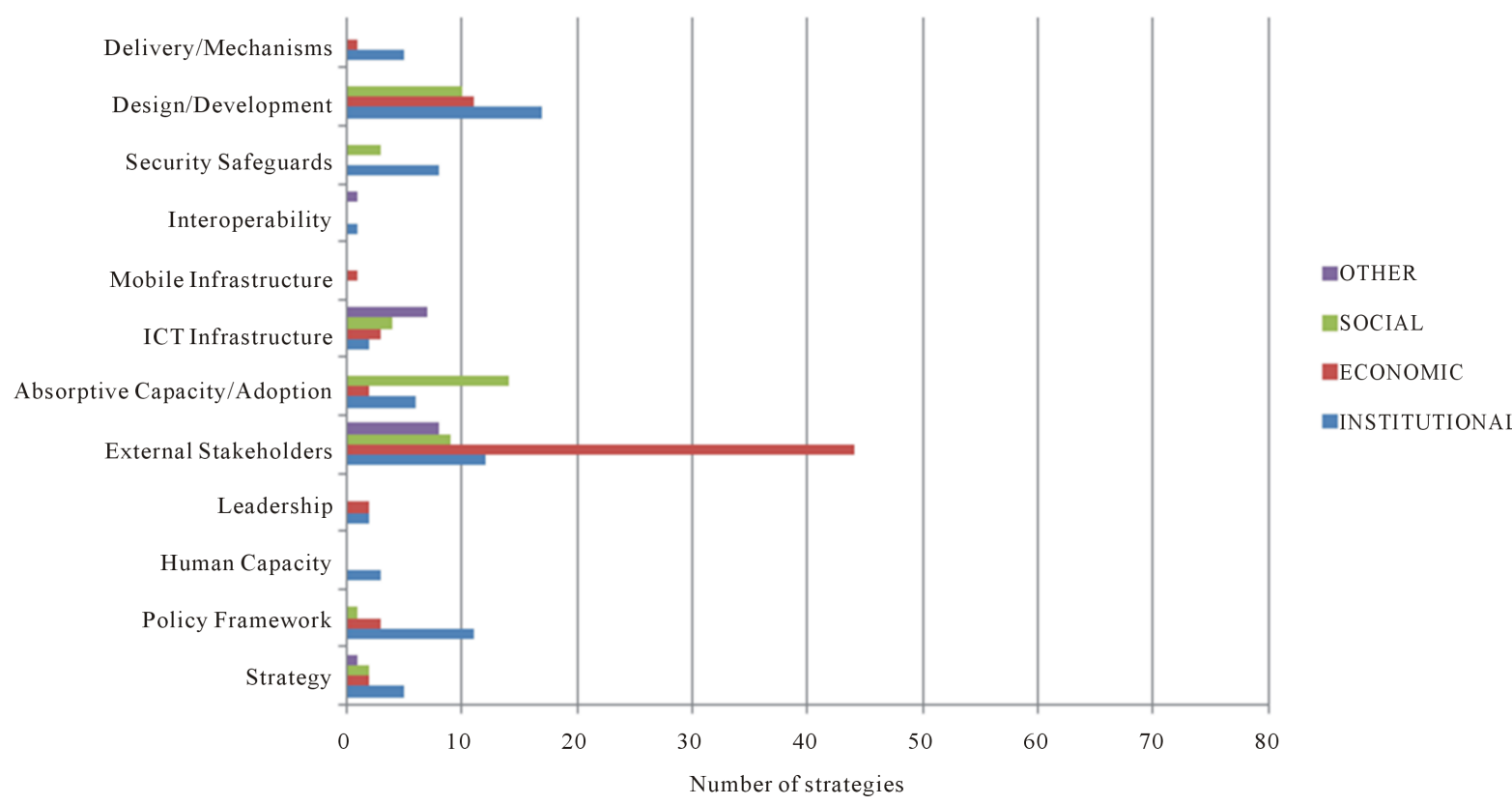

Figure 4. Contribution of MGOV dimensions to SD dimensions-Malta.

\begin{tabular}{|c|c|c|c|c|c|c|c|c|c|c|c|c|c|}
\hline \multirow{3}{*}{ SD DIMENSIONS } & \multicolumn{13}{|c|}{ MGOV DIMENSIONS } \\
\hline & \multicolumn{4}{|c|}{ INSTITUTIONS } & \multicolumn{2}{|c|}{$\begin{array}{l}\text { INNOVATION } \\
\text { SYSTEM }\end{array}$} & \multicolumn{4}{|c|}{ INFRASTRUCTURE } & \multicolumn{2}{|c|}{$\begin{array}{l}\text { SERVICES } \\
\text { APPS }\end{array}$} & \multirow[t]{2}{*}{ SUM } \\
\hline & $\begin{array}{l}\overrightarrow{b 0} \\
\stackrel{0}{\leftrightarrows} \\
\stackrel{\Xi}{5}\end{array}$ & 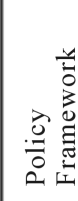 & 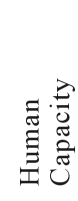 & 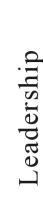 & 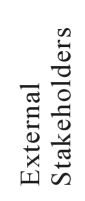 & 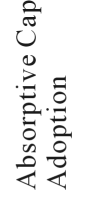 & 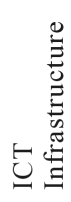 & 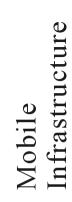 & 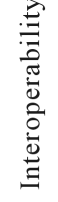 & 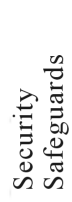 & 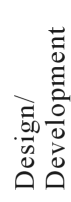 & 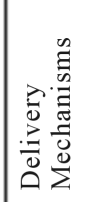 & \\
\hline INSTITUTIONAL & 5 & 11 & 3 & 2 & 12 & 6 & 2 & 0 & 1 & 8 & 17 & 5 & 72 \\
\hline ECONOMIC & 2 & 3 & 0 & 2 & 44 & 2 & 3 & 1 & 0 & 0 & 11 & 1 & 69 \\
\hline ENVIRONMENTAL & 0 & 0 & 0 & 0 & 0 & 0 & 0 & 0 & 0 & 0 & 0 & 0 & 0 \\
\hline SOCIAL & 2 & 1 & 0 & 0 & 9 & 14 & 4 & 0 & 0 & 3 & 10 & 0 & 43 \\
\hline OTHER & 1 & 0 & 0 & 0 & 8 & 0 & 7 & 0 & 1 & 0 & 0 & 0 & 17 \\
\hline SUM & 10 & 15 & 3 & 4 & 73 & 22 & 16 & 1 & 2 & 11 & 38 & 6 & 201 \\
\hline
\end{tabular}

Figure 5. Detailed contribution of MGOV dimensions to SD dimensions-Malta. 


\section{M-Government in Singapore (Institutions \& Development \& Strategies)}

Singapore government's Intelligent Nation 2015 (İn 2015) ICT strategy, m-government strategy has been created in 2005 under the leadership of the Singapore Infocomm Development Agency (IDA) in accordance with the source of their own [29]-[32]. Singapore government in 1980, The National Computerization between 1980-2000 which began as Plan Civil Service Computerization the Programme, to be equivalent to the development of technology and other states has led the strategy of e-government, respectively 2000-2003 e-Government Action Plan 2003-2006 e Government Action Plan 2, 2006-2015 (İn 2015) has planned iGov2010.

E-Government to integrated Government (iGov) strategy aims to; Increasing Reach \& Richness of e-Services, Increasing Citizens’ Mindshare in e-Engagement, Enhancing Capacity \& Synergy in Government, Enhancing National Competitive Advantage. Increasing Reach and richness of e-Services, m-government where the strategy hosting, Infocomm Development Authority of Singapore (IDA) is used by more than 300 mobile applications as active, to be reliable and useful by Singapore citizens has led to its receiving positive feedbacks [33]-[37]. Figure 5 represents ICT strategies in the Singapore in 2015 [38]-[40].

According to statistics Singapore government provided by most of the development strategies (27), then has allocated respectively ,social and institutional development, (14) and other development goals(11) [41] [42].

Figure 6 shows that Singapore's sustainable development objectives of individual mobile government strategy.

According to priority, Singapore İn 2015 ICT Strategy development: economic development through particular institutions, Innovative systems and infrastructure dimensions, Innovation systems, services and applications with dimensions of social and institutional development, multiple development Another strategy (multiple development) mostly with the aim to advance their goals belongs to the infrastructure and innovation system. The Figure 8 is a tabular representation of the data shown in Figure 7 [43].

The MGOV dimensions presents a consolidated pool of MGOV strategies according to the four dimensions of the MGOV framework; Institutions, Innovation System, Infrastructure and Services and Applications [44][45]. The SD Dimensions defined as "Development that meets the needs of the present without compromising the ability of future generations to meet their own needs."

Singapore state e-government and m-government gives rise to slower progress because of Less of the outsourcing of the Singapore government is more than the population, and the recycling (feedback) to be healthy, resource allocation to as the state's need for ICT and infrastructure.

\section{Conclusions}

In conclusion, this study's findings show that e-government to m-government is inevitable. ICT is no longer a branch of technology sees leverage for all sectors. The small island developing States, Malta and Singapore mobile government between were compared with how efficient and effective use and as a result.

Malta began to mobile government application development in 2002. The small population has become easier to get feedback. We also have a strong external sources of Malta, the large budget allocation to the mobile state in terms of internal resources and Malta can be said referring to the support received from the European Union that, Malta has used although a small island country mobile government applications effectively and efficiently.

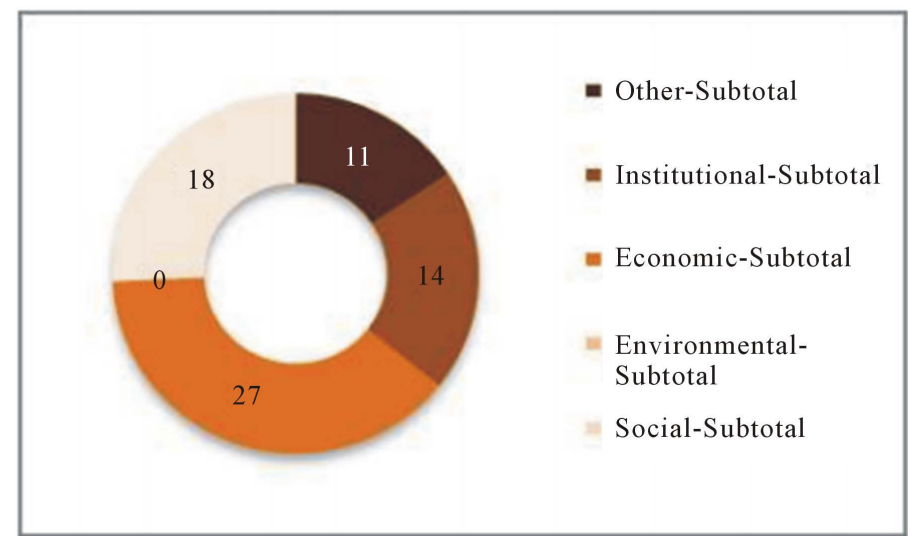

Figure 6. Number of MGOV strategies for SD dimensions-Singapore. 


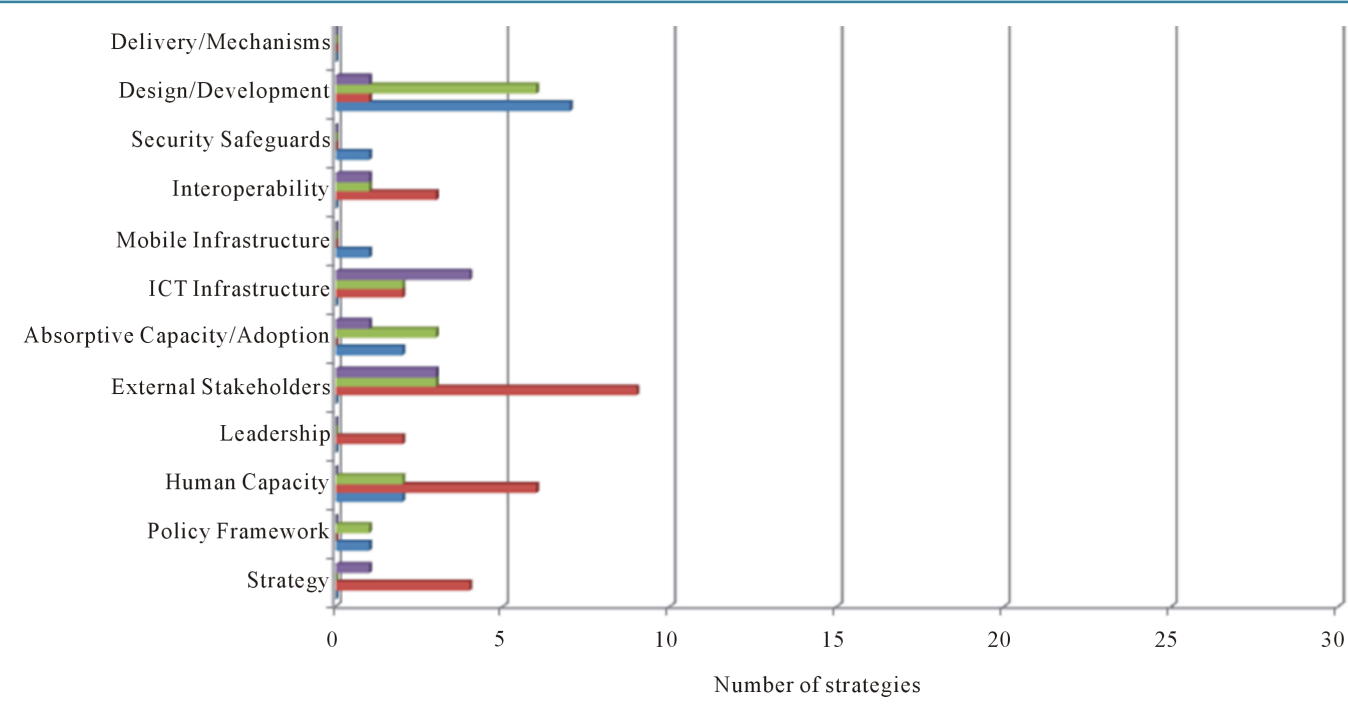

EOTHER

=SOCIAL

-ECONOMIC

EINSTITUTIONAL

Figure 7. Contribution of MGOV dimensions to SD dimensions-Singapore.

\begin{tabular}{|c|c|c|c|c|c|c|c|c|c|c|c|c|c|}
\hline \multirow{3}{*}{ SD DIMENSIONS } & \multicolumn{13}{|c|}{ MGOV DIMENSIONS } \\
\hline & \multicolumn{4}{|c|}{ INSTITUTIONS } & \multicolumn{2}{|c|}{$\begin{array}{l}\text { INNOVATION } \\
\text { SYSTEM }\end{array}$} & \multicolumn{4}{|c|}{ INFRASTRUCTURE } & \multicolumn{2}{|c|}{$\begin{array}{c}\text { SERVICES } \\
\text { APPS }\end{array}$} & \multirow[t]{2}{*}{ SUM } \\
\hline & 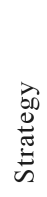 & 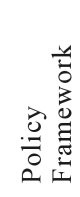 & 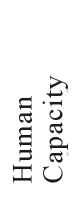 & 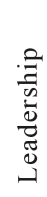 & 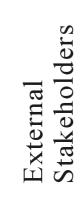 & 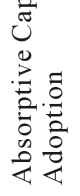 & 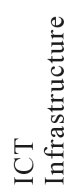 & 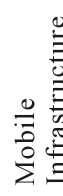 & 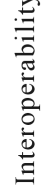 & 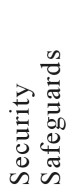 & 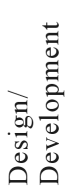 & 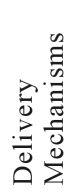 & \\
\hline INSTITUTIONAL & 0 & 1 & 2 & 0 & 0 & 2 & 0 & 1 & 0 & 1 & 7 & 0 & 14 \\
\hline ECONOMIC & 4 & 0 & 6 & 2 & 9 & 0 & 2 & 0 & 3 & 0 & 1 & 0 & 27 \\
\hline ENVIRONMENTAL & 0 & 0 & 0 & 0 & 0 & 0 & 0 & 0 & 0 & 0 & 0 & 0 & 0 \\
\hline SOCIAL & 0 & 1 & 2 & 0 & 3 & 3 & 2 & 0 & 1 & 0 & 6 & 0 & 18 \\
\hline OTHER & 1 & 0 & 0 & 0 & 3 & 1 & 4 & 0 & 1 & 0 & 1 & 0 & 11 \\
\hline SUM & 5 & 2 & 10 & 2 & 15 & 6 & 8 & 1 & 5 & 1 & 15 & 0 & 70 \\
\hline
\end{tabular}

Figure 8. Detailed contribution of MGOV dimensions to SD dimensions-Singapore.

The Singapore government has begun in 1980 to develop mobile applications acted under separate plans each year until 2005. But in 2005, it acted according to plan named Infocomm which was the 10-year plan valid until 2015. Singapore's not too much government budget allocation to the mobile application from its internal budget , less external sources, causes of not too much developing in mobile government. In addition to making any conscious attempt to make it difficult to get feedback because of crowded population of the population is among the reasons why more states develop mobile applications.

\section{References}

[1] (2014) Base Souce: Mobile Governance for Small Island Developing States—Strategy Knowledge Base.

[2] Sari, A. and Necat, B. (2012) Impact of RTS Mechanism on TORA and AODV Protocol's Performance in Mobile Ad Hoc Networks. International Journal of Science and Advanced Technology, 2, 188-191.

[3] Kuschu, İ. and Kuschu, H. (2004) From E-Government to M-Government: Facing the Inevitable. MgovLab.

[4] Sari, A. and Necat, B. (2012) Securing Mobile Ad Hoc Networks against Jamming Attacks through Unified Security Mechanism. International Journal of Ad Hoc, Sensor \& Ubiquitous Computing, 3, 79-94. 
http://dx.doi.org/10.5121/ijasuc.2012.3306

[5] Özbilgin, G. and Çalış, K. (2013) General Comparison of Information and Communication Technologies in Turkey and Azerbaijan.

[6] Sari, A. and Onursal, O. (2013) Role of Information Security in E-Business Operations. International Journal of Information Technology and Business Management, 3, 90-93.

[7] Kocacik, F. (2003) Information Society and Turkey. University of Cumhuriyet, Social Science Magazine.

[8] Sari, A. (2014) Security Approaches in IEEE 802.11 MANET-Performance Evaluation of USM and RAS. International Journal of Communications, Network, and System Sciences, 7, 365-372. http://dx.doi.org/10.4236/ijcns.2014.79038

[9] Erkul, E. (2008) M-Government around the World. eTR Awards and Conference.

[10] Sari, A. (2014) Security Issues in RFID Middleware Systems: A Case of Network Layer Attacks: Proposed EPC Implementation for Network Layer Attacks. Transactions on Networks \& Communications, Society for Science and Education, United Kingdom, 2, 1-6.

[11] United Nations E-Government Survey (2014) E-Government for the Future We Want.

[12] Sari, A. (2014) Economic Impact of Higher Education Institutions in a Small Island: A Case of TRNC. Global Journal of Sociology, 4, 41-45.

[13] Türkiye Bilişim Derneği (TBD) KAMU BİLGİ İŞLEM MERKEZLERİ BİRLİĞİ ÇALIŞMA GRUBU (KAMU-BİB)"Türkiye’de E-devlet Nasil Olmalı?"

[14] Sari, A., Rahnama, B. and Caglar, E. (2014) Ultra-Fast Lithium Cell Charging for Mission Critical Applications. Transactions on Machine Learning and Artificial Intelligence, 2, 11-18. http://dx.doi.org/10.14738/tmlai.25.430

[15] Malta Information Technology Agency (2012) Strategic Plan 2009-2012.

[16] Osterwalder, A. (2015) ICT in Developing Countries.

[17] Sari, A. (2015) Lightweight Robust Forwarding Scheme for Multi-Hop Wireless Networks. International Journal of Communications, Network and System Sciences, 8, 19-28. http://dx.doi.org/10.4236/ijcns.2015.83003

[18] Sandy, G.A. and McMillan, S. (2005) A Success Factors Model for M-Government. EURO mGOV 2005, Brighton, 349-358.

[19] Obasuyi, G. and Sari, A. (2015) Security Challenges of Virtualization Hypervisors in Virtualized Hardware Environment. International Journal of Communications, Network and System Sciences, 8, 260-273. http://dx.doi.org/10.4236/ijcns.2015.87026

[20] Oswin, N. and Yeoh, B.S.A. (2010) Introduction to the Special Issue: Mobile City Singapore. Mobilities, 5, 167-175.

[21] Sari, A., Karaduman, A. and Firat, A. (2015) Deployment Challenges of Offshore Renewable Energy Systems for Sustainability in Developing Countries. Journal of Geographic Information System, 7, 465-477. http://dx.doi.org/10.4236/jgis.2015.75037

[22] CAPAM 2008 Conference, Barbados “Mobile Government”.

[23] Sari, A. (2015) Two-Tier Hierarchical Cluster Based Topology in Wireless Sensor Networks for Contention Based Protocol Suite. International Journal of Communications, Network and System Sciences, 8, 29-42. http://dx.doi.org/10.4236/ijcns.2015.83004

[24] National Statistics Office (2012) ICT Usage by Enterprises and Households 2011. National Statistics Office, Valletta.

[25] Sari, A. and Mahmutoglu, H. (2013) Potential Issues and Impacts of ICT Applications through Learning Process in Higher Education. Procedia-Social and Behavioral Sciences, 89, 585-592. http://dx.doi.org/10.1016/j.sbspro.2013.08.899

[26] Sari, A. (2012) Impact of Determinants on Student Performance towards Information Communication Technology in Higher Education. International Journal of Learning and Development, 2, 18-30. http://dx.doi.org/10.5296/ijld.v2i2.1371

[27] The National ICT Strategy for Malta (2008-2010). The Smart Island. http://unpan1.un.org/intradoc/groups/public/documents/UNPAN/UNPAN034350.pdf

[28] Güler, M. and Döventaş, E. (2009) Elektronik Devletten (E-Devlet) Mobil Devlete (M-Devlet) Geçişte Türkiye’de Yerel Yönetim Uygulamalari.

[29] Sari, A. (2015) A Review of Anomaly Detection Systems in Cloud Networks and Survey of Cloud Security Measures in Cloud Storage Applications. Journal of Information Security, 6, 142-154. http://dx.doi.org/10.4236/jis.2015.62015

[30] Trimi, S., Lee, S.M. and Tan, X. (2005) Current Practices of Leading E-Government Countries. Communications of the 
ACM, 48, 99-104.

[31] Ghyasi, F. and Kushchu, I. (2004) M-Government: Cases of Developing Countries. mGovLab, International University of Japan, Niigata Prefecture.

[32] Al-Khamayseh, S., Lawrence, E. and Zmijewska, A. (2006) Towards Understanding Success Factors in Interactive Mobile Government. University of Technology, Sydney.

[33] Sari, A. and Rahnama, B. (2013) Simulation of 802.11 Physical Layer Attacks in MANET. Proceedings of the 2013 Fifth International Conference on Computational Intelligence, Communication Systems and Networks (CICSyN), Madrid, 5-7 June 2013, 334-337. http://dx.doi.org/10.1109/CICSYN.2013.79

[34] Al-khamayseh, S. and Lawrence, E. (2006) Towards Citizen Centric Mobile Government Services: A Roadmap.

[35] Sari, A. (2014) Influence of ICT Applications on Learning Process in Higher Education. Procedia-Social and Behavioral Sciences, 116, 4939-4945. http://dx.doi.org/10.1016/j.sbspro.2014.01.1053

[36] Digital Services Advisory Group and Federal Chief Information Officers Council (2012) Government Use of Mobile Technology.

[37] Sari, A. and Rahnama, B. (2013) Addressing Security Challenges in WiMAX Environment. In: Proceedings of the 6th International Conference on Security of Information and Networks (SIN'13), ACM Press, New York, 454-456. http://doi.acm.org/10.1145/2523514.2523586 http://dx.doi.org/10.1145/2523514.2523586

[38] Negroponte, N. (1998) One Room Schools. Wired 09/06/98.

[39] University of Hitit Social Science Institute Magazine, June 2009 (25-48).

[40] Rahnama, B., Sari, A. and Makvandi, R. (2013) Countering PCIe Gen. 3 Data Transfer Rate Imperfection Using Serial Data Interconnect. Proceedings of the 2013 International Conference on Technological Advances in Electrical, Electronics and Computer Engineering (TAEECE), Konya, 9-11 May 2013, 579-582. http://doi.acm.org/10.1109/TAEECE.2013.6557339.

[41] Mobile Governance for Small Island Developing States—Strategy Knowledge Base, 28 April 2014.

[42] Singapore Infocomm Development Agency, 2006.

[43] The Brundtland Commission (1987) Report of the World Commission on Environment and Development: Our Common Future. Oxford University Press, Oxford.

[44] Oui-Suk, U. (2010) Introduction of m.Government \& IT Convergence Technology. Working Document, KAIST Institute for IT Convergence, Daejeon.

[45] The White House (2014) Digital Government, Building a 21st Century Platform to Better Serve the American People. The Executive Office of the President of the United States.

http://www.whitehouse.gov/sites/default/files/omb/egov/digital-government/digital-government.html 